\title{
Serum zinc levels in hospitalized children with pneumonia: a hospital-based case-control study
}

\author{
Amira M.M. Hamed ${ }^{\mathrm{a}}$, Yasser T. Kassem ${ }^{\mathrm{a}}$, Hamada K. Fayed ${ }^{\mathrm{b}}$, \\ Ahmed M. Solaiman ${ }^{\mathrm{C}}$
}

\begin{abstract}
Background Zinc is an important micronutrient in humans. Globally, pneumonia represents $18 \%$ of mortality in children under 5 years of age and the main infectious purpose of early life mortality. There is a higher pneumonia risk in a population with zinc deficiency. The aim of our study is to compare the level of serum zinc in children with pneumonia with age, sex, and nutritional matched healthy controls.
\end{abstract}

Patients and methods Serum zinc level in 90 children admitted with pneumonia was compared with the matched controls.

Results The mean level of serum zinc in children with pneumonia $(67.5 \pm 21.8)$ is significantly lower than that of controls $(91.8 \pm 19.94)$ with $(P<0.001)$.

Conclusion Children with pneumonia has a significantly lower serum zinc levels than matched healthy controls.

\section{Introduction}

Acute respiratory tract infection is the leading cause of below-five mortality in kids [1]. Pneumonia is an acute form of respiratory infection that impacts the lungs. It is defined as an inflammation of the lung tissue due to an infectious agent. The commonly used clinical WHO operational definition is based only on clinical symptoms (cough or difficulties in breathing and tachypnea). In the developing world, the term lower respiratory tract infection is widely used instead of pneumonia, because of poor access to radiography and difficulties in radiological confirmation of diagnosis [2].

Pneumonia is the only major infectious cause of pediatric mortality internationally. Pneumonia death is about 920000 children under the age of 5 years in 2015 , representing $16 \%$ of all pediatric mortality below 5 years old. Pneumonia influences children and families everywhere, however, is most usual in South Asia and Sub-Saharan Africa. Children can be avoided with easy interventions and treated with low-cost, low technical medication, and care [3]. In Egypt, it was estimated that $10 \%$ of deaths in children under the age of 5 years is probably caused by pneumonia and other acute respiratory infections [4].

Zinc affects many elements of the immune device, from the skin barrier to gene regulation inside lymphocytes. The function of macrophage is adversely affected by zinc deficiency. Zinc plays a crucial role in the development of acquired immunity, immunoglobulin
Egypt J Bronchol 2019 13:730-737

(C) 2020 Egyptian Journal of Bronchology

Egyptian Journal of Bronchology 2019 13:730-737

Keywords: children, breastfeeding, pneumonia, zinc

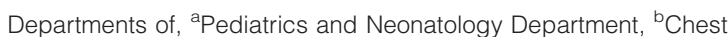
Diseases, ${ }^{\circ}$ Clinical Pathology, Al-Azhar University Hospital, Assiut, Egypt

Correspondence to Fayed H. Kawshty, MD, Department of Chest Diseases, Al-Azhar University Hospital, Al Forsan Building, Al-Azhar Street, Assiut City, Assiut, Egypt. Tel: +20 109332 6825; fax: 0882149358; e-mail: kawshtey1978@yahoo.com

Received: 7 April 2019 Accepted: 30 April 2019

Published: 21 January 2020

$\mathrm{G}$ production, intracellular killing, cytokine production, and phagocytosis, thus regulating the defense mechanism in children with acute infection [5]. Prophylactic zinc therapy decreases the rate of infection in children with pneumonia [6].

Deficiency of zinc reduces the body's ability to reply to infection and additionally adversely influences both cell-mediated and humoral immune responses. The impaired immunocompetence due to low zinc states enhances the establishment of a particular infection due to a reduction in the clearance of infectious agents [7].

The purpose of our study was to compare the serum zinc level in children admitted with pneumonia to the matched controls and assess its relationship to the grade of respiratory distress.

\section{Patients and methods}

A comparative, cross-sectional hospital-based study was carried out from November 2016 to October 2018. The total of 180 children included in the study was classified into two groups as follows: group I, the cases group: included 90 children with clinical and laboratory evidence of pneumonia

This is an open access journal, and articles are distributed under the terms of the Creative Commons Attribution-NonCommercial-ShareAlike 4.0 License, which allows others to remix, tweak, and build upon the work non-commercially, as long as appropriate credit is given and the new creations are licensed under the identical terms. 
attending the pediatric department and group II, the control group: included 90 children who are seemingly healthy controls who attended for nonchest problem or dangerous medical condition. Parents of all patients and controls gave their informed consents and written approval for their children's participation before their enrollment in the study. The study was approved by the local moral committee of our university, to assess and submit facts. Written or verbal consent was taken from parents or from close guardian.

\section{Inclusion criteria}

Children aged between 2 months and as much as 5 years on admission identified as pneumonia were recruited as patients.

\section{Exclusion criteria}

(a) Children of age less than 2 months; (b) children over 5 years of age; (c) children who had upper respiratory tract infection or viral infection such as bronchiolitis; (d) children with diarrhea in the previous 1 month; (e) excessive form of malnutrition such as marasmus; (f) history and manifestation of liver, heart illness, or history of intake of zinc supplements within the preceding 1 month.

All children were clinically examined by the treating physician and treatment ordered by way of them was abstracted. These children were confirmed radiologically with a chest radiograph. All cases were subjected to a complete clinical study (through history and physical examination) upon study inclusion, with emphasis on symptoms and signs of pneumonia.

Complete diagnostic workup including complete blood count, $\mathrm{C}$-reactive protein (CRP), renal function test, and blood culture was done. In all children, serum zinc level was measured in $2 \mathrm{ml}$ of a venous blood sample taken at the time of admission or within $24 \mathrm{~h}$ of admission after obtaining consent from parents. Serum zinc level was measured by spectrophotometry using the calorimetric method (Quanticore TM Zinc Assay Kit; Bioassay Systems, Hayward, USA).

\section{Results}

The study population consists of 180 children with 90 cases with pneumonia (48 men and 42 women) and 90 healthy controls of matched age and sex (48 men and 42 women). The mean age of the patient group was $20.6 \pm 15.7$ and $22.3 \pm 19.9$ months for the control group and there was no statistically significant difference between groups $(P>0.05)$. There is no significant difference between patients and control group as regards sex, residence, history of exposure to smoking, weight, and height $(P>0.05)$ while there was significant difference between patients and controls as regards the type of supplementation $(P<0.05$, Table 1), where supplementation is significantly lower in children with pneumonia than their matched controls $(P<0.05$, Table 2$)$.

There was a statistically significant decrease in mean corpuscle volume, mean corpuscle hemoglobin, and lymphocyte percentage in patients when compared with controls $(P<0.05)$, while there was a statistically significant increase in white blood cell and its differential (neutrophil, staff) count and CRP level in patients when compared with controls $(P<0.05)$.

Mean serum zinc level in children with pneumonia was $67.5 \pm 21.8 \mu \mathrm{g} / \mathrm{dl}$, while that of matched controls was $91.8 \pm 19.94 \mu \mathrm{g} / \mathrm{dl}$. Mean serum zinc level is significantly lower in children with pneumonia than

\begin{tabular}{|c|c|c|c|}
\hline Parameters & $\begin{array}{l}\text { Patients } \\
(N=90)\end{array}$ & $\begin{array}{l}\text { Controls } \\
(N=90)\end{array}$ & $\begin{array}{c}P \\
\text { value }\end{array}$ \\
\hline $\begin{array}{l}\text { Age of the child (months) } \\
(\text { mean } \pm S D)\end{array}$ & $20.6 \pm 15.7$ & $22.3 \pm 19.9$ & 0.16 \\
\hline Range (minimum-maximum) & $58(2-60$ & $57(3-60)$ & \\
\hline \multicolumn{4}{|l|}{$\operatorname{Sex}[n(\%)]$} \\
\hline Male & $48(53.3)$ & 39 (43.3) & 0.44 \\
\hline Female & $42(46.7)$ & $51(56.7)$ & \\
\hline \multicolumn{4}{|l|}{ Residence [n (\%)] } \\
\hline Urban & 30 (33.3) & $27(30.0)$ & 0.78 \\
\hline Rural & $60(66.7)$ & $63(70.0)$ & \\
\hline \multicolumn{4}{|l|}{$\begin{array}{l}\text { History of exposure to } \\
\text { smoking }[n(\%)]\end{array}$} \\
\hline No & $72(80.0)$ & 75 (83.3) & 0.5 \\
\hline Yes & $18(20.0)$ & $15(16.7)$ & \\
\hline \multicolumn{4}{|l|}{ Place of admission [n (\%)] } \\
\hline Ward & $54(60)$ & - & \\
\hline PICU & $36(40)$ & - & \\
\hline \multicolumn{4}{|l|}{ Weight-for-age $[n(\%)]$} \\
\hline$<5$ th & $18(20.0)$ & $9(10.0)$ & 0.74 \\
\hline$\geq 5$ th & $72(80.0)$ & $81(90.0)$ & \\
\hline \multicolumn{4}{|l|}{ Height-for-age [n (\%)] } \\
\hline$<5$ th & $9(10.0)$ & $6(6.7)$ & 0.8 \\
\hline$\geq 5$ th & $81(90.0)$ & $84(93.3)$ & \\
\hline
\end{tabular}

PICU, pediatric intensive care unit.

Table 2 Comparison between patients and controls regarding the type of supplementation (total $N=180$ )

\begin{tabular}{lccc}
\hline Supplementation & Patients $[n(\%)]$ & Controls $[n(\%)]$ & \\
\hline No $(N=48)$ & $33(36.7)$ & $15(16.7)$ & $0.041^{*}$ \\
Iron $(N=12)$ & $3(3.3)$ & $9(10)$ & \\
Iron+vitamins $(N=69)$ & $21(23.3)$ & $48(53.3)$ & \\
Vitamins $(N=51)$ & $33(36.7)$ & $18(20)$ & \\
\hline
\end{tabular}

${ }^{*} P$ value is statistically significant. 
Table 3 Comparison between patients and controls regarding complete blood count, serum zinc level, and C-reactive protein $(N=180)$

\begin{tabular}{|c|c|c|c|}
\hline Parameters & Patients $(N=90)$ & Controls $(N=90)$ & $P$ value \\
\hline $\mathrm{RBCs} \times 10^{6}(\mathrm{~cm})($ mean $\pm \mathrm{SD})$ & $4.46 \pm 0.9$ & $4.18 \pm 0.49$ & 0.13 \\
\hline HB (g/dl) (mean $\pm S D)$ & $10.12 \pm 2.06$ & $10.53 \pm 1.23$ & 0.36 \\
\hline $\mathrm{HCT}($ mean $\pm \mathrm{SD})$ & $29.7 \pm 6.04$ & $31.8 \pm 4.56$ & 0.13 \\
\hline MCV (fl) (mean $\pm S D)$ & $67.3 \pm 10.8$ & $75.74 \pm 7.25$ & $0.001^{* *}$ \\
\hline $\mathrm{MCH}(\mathrm{pg})($ mean $\pm \mathrm{SD})$ & $23.09 \pm 3.56$ & $24.88 \pm 2.44$ & $0.028^{*}$ \\
\hline $\mathrm{MCHC}(\mathrm{pg})($ mean $\mathrm{SD})$ & $34.14 \pm 3.11$ & $33 \pm 1.57$ & 0.75 \\
\hline Platelet count $\times 10^{3}($ mean $\pm S D)$ & $373.4 \pm 139.5$ & $321.8 \pm 89.2$ & 0.094 \\
\hline Lymphocyte (mean \pm SD) & $29.06 \pm 14.6$ & $37.42 \pm 11.5$ & $0.016^{*}$ \\
\hline WBCs $\times 10^{3}(\mathrm{~cm})($ mean $\pm S D)$ & $18.53 \pm 9.66$ & $9.81 \pm 4.9$ & $0.001^{* *}$ \\
\hline Eosinophil (meanะSD) & $2.13 \pm 0.83$ & $3.12 \pm 1.75$ & 0.14 \\
\hline Neutrophil (mean $\pm S D)$ & $63 \pm 15.3$ & $54.1 \pm 11.9$ & $0.013^{*}$ \\
\hline Monocyte (mean $\pm S D$ ) & $6.15 \pm 4.9$ & $3.8 \pm 1.92$ & 0.32 \\
\hline Staph (mean $\pm S D)$ & $2.43 \pm 1.61$ & $0.67 \pm 0.13$ & $0.011^{*}$ \\
\hline Segmented (mean $\pm S D)$ & $55.6 \pm 17.5$ & $52.7 \pm 19.7$ & 0.073 \\
\hline Serum zinc $(\mu \mathrm{g} / \mathrm{dl})($ mean $\pm S D)$ & $67.5 \pm 21.8$ & $91.8 \pm 19.94$ & $0.001^{* *}$ \\
\hline $\operatorname{CRP}[n(\%)]$ & & & $0.001^{* *}$ \\
\hline$-v e$ & $24(26.7)$ & $72(80)$ & \\
\hline +ve & $66(73.3)$ & $18(20)$ & \\
\hline
\end{tabular}

$\mathrm{CRP}$, C-reactive protein; $\mathrm{HB}$, hemoglobin; $\mathrm{HCT}$, hematocrit; $\mathrm{MCH}$, mean corpuscle hemoglobin; MCHC, mean corpuscle hemoglobin concentration; MCV, mean corpuscle volume; RBCs, red blood cells; WBCs, white blood cells. ${ }^{\star} P$ value is statistically significant. ${ }^{\star \star} P$ value is statistically highly significant.

their matched controls $(P<0.001)$ (Table 3). There was no significant correlation between $\mathrm{CRP}$ results and serum zinc level in patients $(r=-0.1, P=0.49)$ and controls $(r=-0.28, P=0.29)$ (Figs 1, 2).

Mean serum zinc level in the patient group is compared with the degree of respiratory distress. There was a significant difference in mean serum zinc level between patients when compared with the degree of respiratory distress $(P<0.05)$, where higher values of zinc were reported with lower grades of respiratory distress (Table 4).

There was no significant difference in serum zinc level between patients as regards the type of feeding $(P>0.05)$, while there was a significant difference in serum zinc level between controls as regards the type of feeding $(P<0.05)($ Table 5).

There was a highly significant decrease in serum zinc level of patients with complications such as pleural effusion or empyema $(43.8 \pm 15.4)$ than that without complications $(72.25 \pm 19.8)(P<0.001)$ (Fig. 3).

There was a significant difference in mean serum zinc level of patients as regards the place of admission in a ward $(66.7 \pm 16.6)$ or PICU $(60.3 \pm 11.6)(P<0.05)$.

\section{Statistical analysis}

The collected data were collected, prepared, tabulated, and statistically analyzed using the Statistical Package for the Social Sciences (SPSS), version 23.0 for Windows. Enumeration data were presented as mean $\pm \mathrm{SD}$ and were analyzed with an unpaired $t$ test. Categorical variables were analyzed with Pearson $\chi^{2}$ and Fisher's exact tests. The statistical methods were verified, assuming a significance level of $P$ value less than 0.05 and a highly significant level of $P$ value less than 0.001 .

\section{Discussion}

Pneumonia is one of acute lower respiratory infections that involve the airways and parenchyma with a consolidation of alveolar spaces (infection of the lung alveoli) [8]. In Egypt, it was estimated that 10\% of death in children under the age of 5 years is usually caused by pneumonia and other acute respiratory infections [3]. The occurrence and mortality of pneumonia is adversely affected by malnutrition. Malnutrition has been identified as an important determinant of pneumoniarelated mortality [7].

Zinc is an essential element required for cell metabolism and immunity. Therefore, zinc deficiency leads to susceptibility to infections and may affect pulmonary epithelial cell integrity. Several investigators have used zinc supplementation to see its effect on many diseases mainly diarrheal diseases and severe pneumonia [9].

The incidence of pneumonia is high in the young age that may be due to a defect in the complex system of 


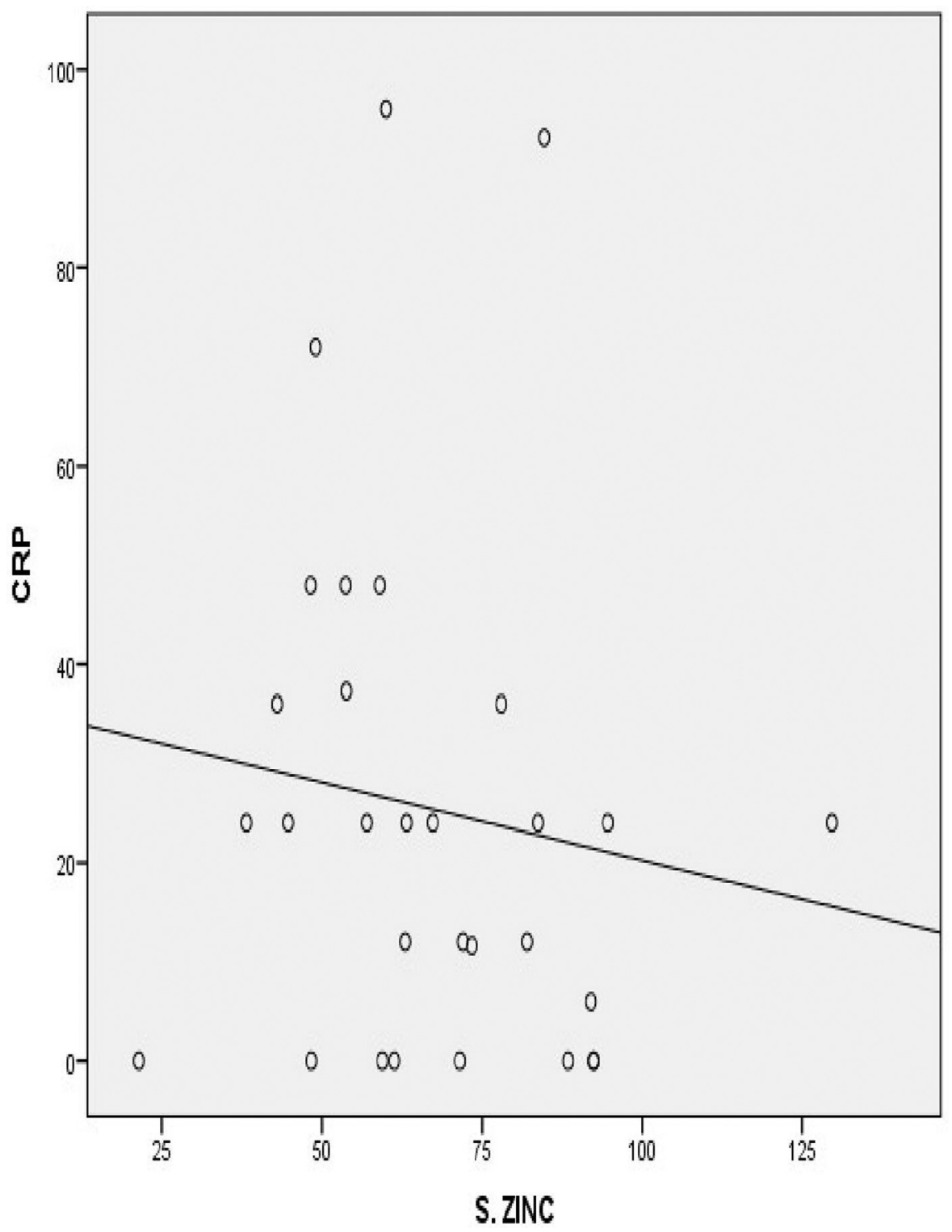

Scatter diagram showing the correlation between CRP results and serum zinc among patients. CRP, C-reactive protein.

defense mechanisms which normally protect the lungs from a hostile microbiological environment. These include physical defenses such as cough and mucociliary clearance, circulating and resident cellular defenses, and a range of humeral or secretory mechanisms and may be due to restricted access to zinc-rich ingredients (animal products, oysters, and shellfish) and the abundance of zinc inhibitors which include phytate [10].

Our study reported that the mean age for children with pneumonia was 20.6 months. This result was higher than the results found in studies undertaken in Uganda and Nepal by Srinivasan et al. [11] and Basnet et al. [12], respectively, who reported that the mean age of their children was $17.9 \pm 12.2$ and $7.8 \pm 6.0$ months, respectively. The mean age of our patients was lower than that reported by Shah et al. [13] in their cases (108 \pm 60 months). This difference found in the studied patients may be due to a wide variation in the causative organisms.

In our study, we reported that male patients were affected by pneumonia more than females. This male predominance was also recorded by ValentinerBranth et al. [14] (58\%), Basnet et al. [12] (59.2\%), and Jagnoor et al. [15] (52.8\%).

Anatomic, way of life, behavioral, and socioeconomic differences between men and women may explain the located findings. The role of sex hormones in the regulation of the immune system can be additionally contributing to the reported sex differences in the occurrence and 


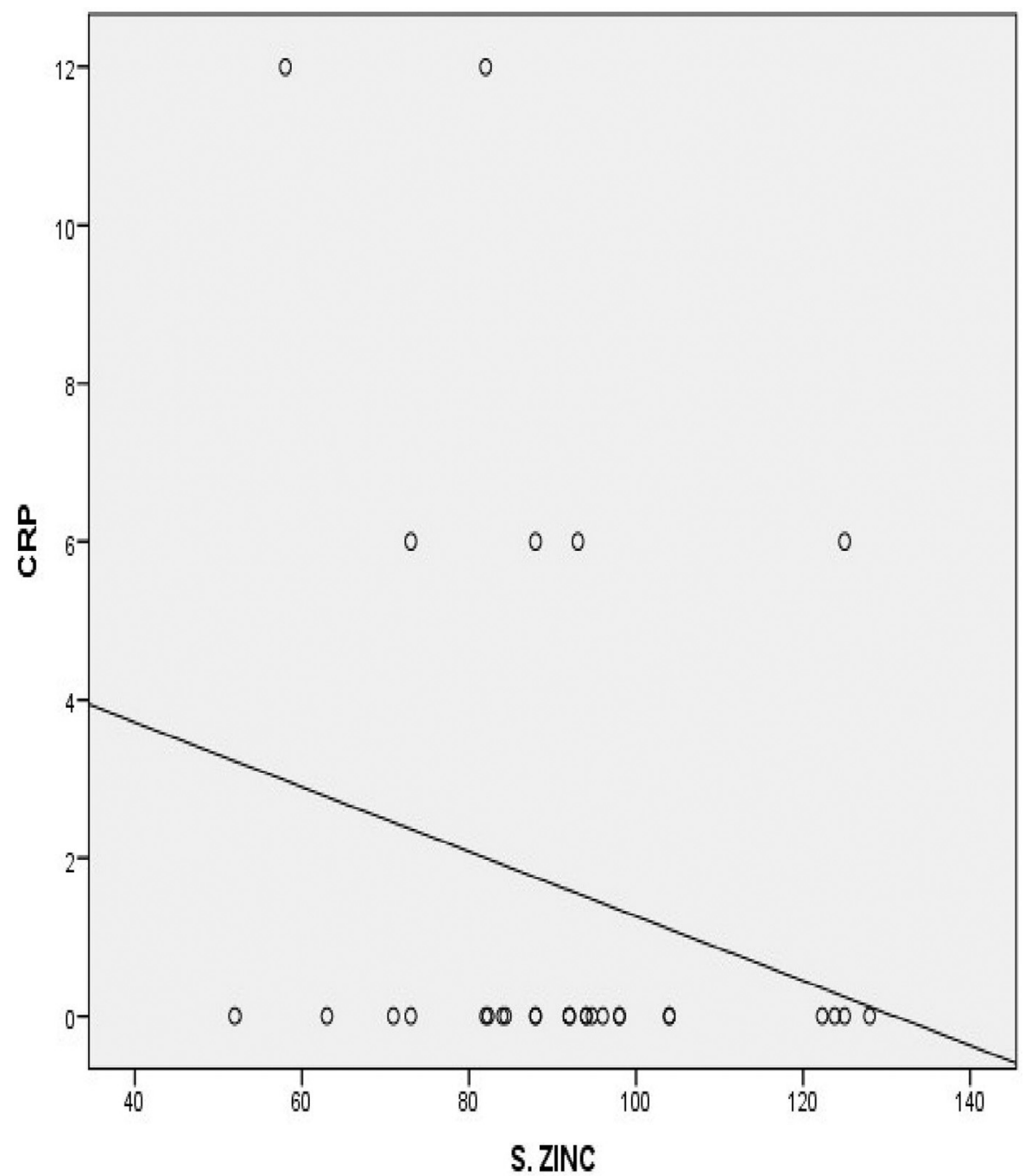

Scatter diagram showing the correlation between CRP results and serum zinc among controls. CRP, C-reactive protein.

severity of the several types of respiratory tract infections [16].

The current study observed that there was a significant increase in CRP level in patients when compared with controls (Table 3). This may be due to the manufacturing of plasma CRP from the liver in response to an infection or harm to the tissue and inflammatory processes, so the antiinflammatory effect of zinc may increase the CRP level [17].

Our study was consistent with the results observed by Cvijanovich et al. [18] who observed low plasma zinc levels in 20 critically ill children and its levels correlated inversely with markers of inflammation such as CRP and grade of organ failure.

There was a significant difference in serum zinc level between patients and controls as regards the type of
Table 4 Comparison of serum zinc level according to the degree of respiratory distress among patients $(N=90)$

\begin{tabular}{|c|c|c|c|c|}
\hline & $\begin{array}{l}\text { Mild } \\
(N=27)\end{array}$ & $\begin{array}{l}\text { Moderate } \\
(N=39)\end{array}$ & $\begin{array}{l}\text { Severe } \\
(N=24)\end{array}$ & $\begin{array}{c}P \\
\text { value }\end{array}$ \\
\hline $\begin{array}{l}\text { Serum zinc }(\mu \mathrm{g} / \mathrm{dl}) \\
(\text { mean } \pm S D)\end{array}$ & $\begin{array}{r}72.5 \\
\pm 24.7\end{array}$ & $61.4 \pm 21.5$ & $55.2 \pm 17.2$ & $0.002^{*}$ \\
\hline
\end{tabular}

${ }^{*} P$ value is statistically significant.

feeding and supplementation (Table 4). There was a significant difference in serum zinc level between controls as regards the type of feeding (Table 4). This may be due to that breastfeeding protects the infants from getting pneumonia by way of boosting their infection-fighting (immune) system. Breastfeeding beyond 4 months of age offers satisfactory protection [19].

In agreement with our results, Arica et al. [20] reported that there is a high concentration of zinc in breast-fed infants especially colostrum. 
Table 5 Comparison of serum zinc level according to feeding type among patients and controls $(N=60)$

\begin{tabular}{lcccc}
\hline Serum zinc $(\mu \mathrm{g} / \mathrm{dl})($ mean $\pm \mathrm{SD})$ & Breastfeeding & Breast and artificial feeding & Artificial feeding & $P$ value \\
\hline Total number of patients & $N=111$ & $N=39$ & $N=30$ & $64.6 \pm 19.2$ \\
& $85.07 \pm 23.9$ & $75.7 \pm 22.5$ & $N=15$ & $0.041^{*}$ \\
Patient group & $N=45$ & $N=30$ & $53.8 \pm 21.03$ & 0.21 \\
& $67.1 \pm 19.2$ & $75 \pm 24.4$ & $N=15$ & $0.027^{*}$ \\
Control group & $N=66$ & $N=9$ & $75.4 \pm 9.76$ & \\
& $97.33 \pm 18.8$ & $78.1 \pm 13.36$ & & \\
\hline
\end{tabular}

${ }^{*} P$ value is statistically significant.

Figure 3

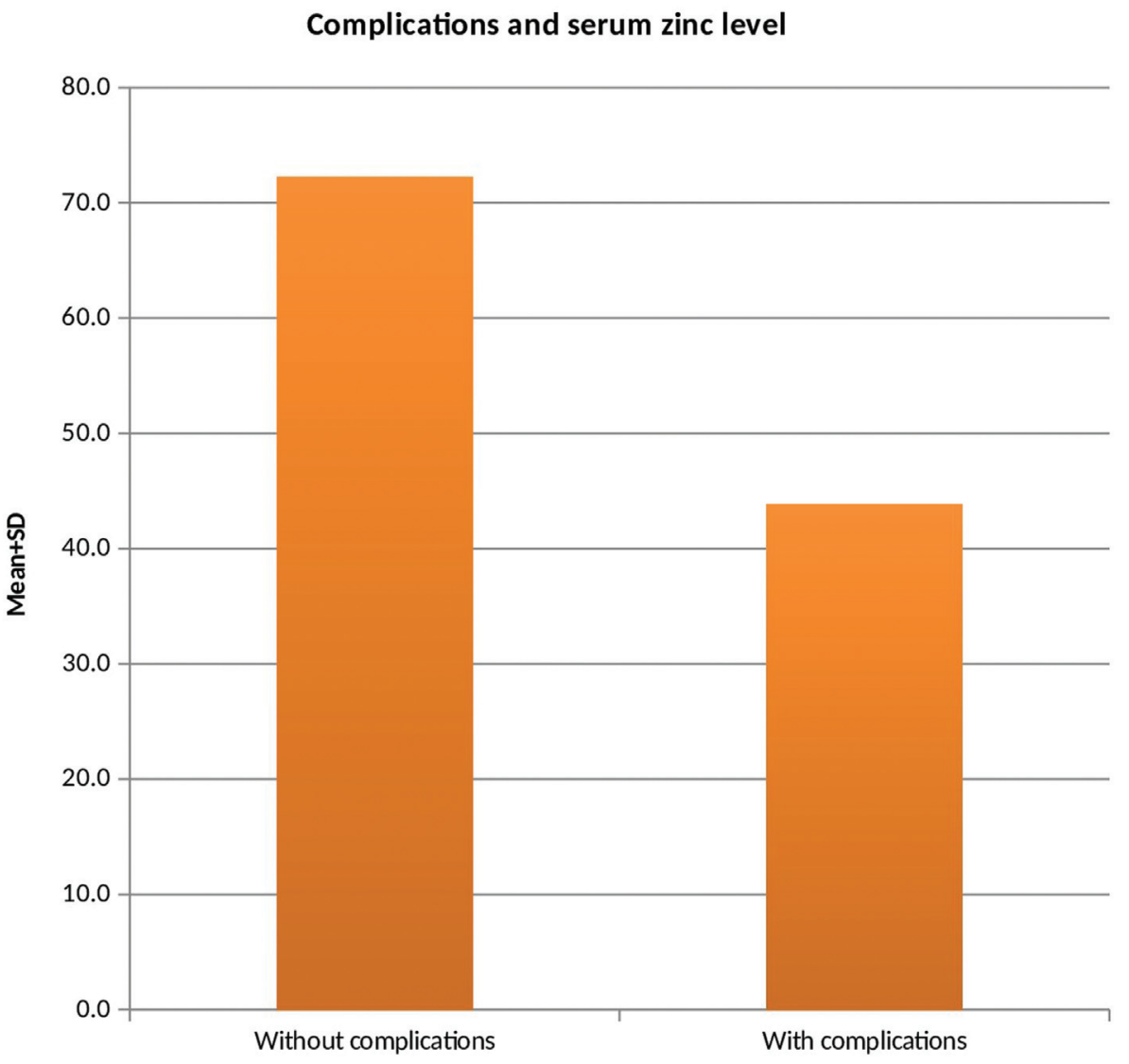

Comparison of serum zinc level according to complications among patients $(N=90)$.

The current study found that there was a significant difference in serum zinc level between patients as regards the grading of respiratory distress. Our results agreed with Bhandari et al. [21] who found that there was a wide decrease in the duration of hospitalization and recovery from pneumonia in zinc receiving children. This suggests the effect of zinc therapy and a change in the clinical course of pneumonia among the children.

This agreed with the study by Rahim et al. [22] who suggested that zinc through its antioxidant effect may improve symptoms of respiratory tract infection.
There was a significant decrease in serum zinc level of patients with complications (pleural effusion or empyema) than that without complications of pneumonia (Figs 3 and 4). This may be due to that zinc reduces susceptibility to pneumonia by regulating several immune functions, including protecting the health and integrity of the respiratory cells during lung inflammation or injury resulting in improvement of respiration [23].

Our study has shown that there was a significant difference in serum zinc level between patients as regards the site of admission which is either in a ward or PICU. This can be explained by the role of 


\section{Figure 4}

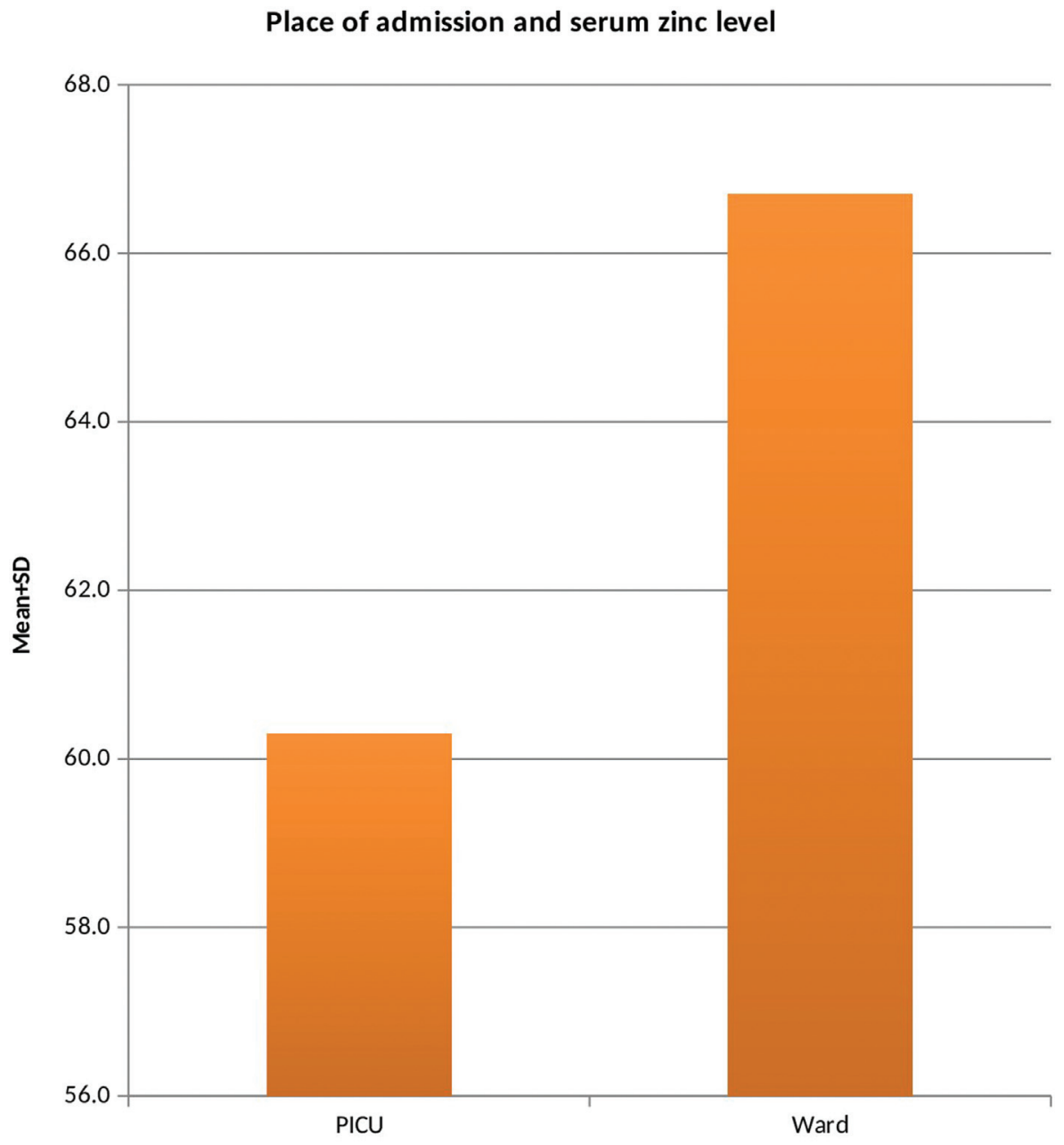

Comparison of serum zinc level according to the place of admission, among patients $(N=90)$.

zinc in decreasing inflammation resulting in an improvement of respiratory distress. Zinc deficiency may harm mucosal integrity. Zinc helps revitalize mucus membranes. It is suggested that the antioxidant effect of zinc may improve symptoms of respiratory tract infection [23].

The mean serum zinc levels in patients were significantly lower than the corresponding level for controls. This may be due to that a defensive reaction to infection as zinc has a direct antiviral effect and an observable impact on immunemediated production of interferon. Additionally, zinc prevents pathogens from gaining entry into cells and hinders their intracellular multiplication [7]. Also, perhaps because zinc deficiency impairs standard immune feature and resistance to infection [24].In agreement with our study, Panneerselam and Marimuthu [25] mentioned that their mean serum zinc level in the patient group (60.98) is significantly lower than that of controls (73.124) with $(P=0.001)$.
Our result was in agreement with the results reported by Brooks et al. [26], Mahalanabis et al. [27], and Srinivasan et al. [14] studies. They reported that their mean serum zinc levels were 52.7, 66.01, and $62.75 \mu \mathrm{g} /$ dl, respectively.

Our study was consistent with the results documented by the Shakur et al. [28] and Shakur et al. [9] studies. They reported that their mean serum zinc levels were 63.7 and $57.9 \mu \mathrm{g} / \mathrm{dl}$; respectively. In India, Kumar et al. [29] reported that serum zinc level was significantly lower in patients with pneumonia compared with the control cases.

Our results disagreed with the results observed by Anuradha et al. [30] $(71.9 \mu \mathrm{g} / \mathrm{dl})$ and Rady et al. [31] $(80.77 \mu \mathrm{g} / \mathrm{dl})$. This may be explained by a longer period of breastfeeding in her study group and the known fact that high concentration of zinc is included in colostrum. 
Further studies are required to recommend routine intake of zinc in children to prevent pneumonia and the therapeutic use of zinc in pneumonia. The chief limitation of our study is follow-up with zinc intake and its impact is not recorded.

\section{Conclusion}

Serum zinc levels are significantly low in children with pneumonia when compared with healthy controls. There is a negative correlation between serum zinc level and the grade of respiratory distress among children with pneumonia. The low serum zinc level determined in children with pneumonia usually due to zinc deficiency highlights the significance of the inclusion of food items containing good amounts of zinc in children's diet.

\section{Financial support and sponsorship}

Nil.

\section{Conflicts of interest}

There are no conflicts of interest.

\section{References}

1 Saleh NY, Fotoh WMMAE. Low serum zinc level: the relationship with severe pneumonia and survival in critically ill children. Int J Clin Pract 2018; 72: 13211.

2 World Health Organization. Pneumonia; 2011. Available at: http://www who.int/mediacentre/factsheets/fs331/en. [Accessed 5 June 2013].

3 World Health Organization. World Health Statistics. Geneva, Switzerland World Health Organization; 2014. Available on the WHO website (www. who.int)

4 World Health Organization. Pneumonia diagnosis and management Geneva, Switzerland: World Health Organization; 2015.

5 Shankar AH, Prasad AS. Zinc and immune function: the biological basis of altered resistance to infection. Am J Clin Nutr 1998; 68:447-463.

6 Lassi ZS, Moin A, Bhutta ZA. Zinc supplementation for the prevention of pneumonia in children aged 2 months to 59 months. Cochrane Database Syst Rev 2016; 12:59-78.

7 Ibraheem RM, Johnson AB, Abdulkarim AA, Biliaminu SA. Serum zinc levels in hospitalized children with acute lower respiratory infections in the north-central region of Nigeria. Afr Health Sci 2014; 14:136-142.

8 Abhiram I, Panchanathan S, Ganesan R, Jenifer A. Serum zinc level: a prognostic marker for severe pneumonia in children. Int $J$ Contemp Pediatr 2019; 6:2349-2391.

9 Shakur MS, Malek MA, Bano N, Rahman M, Ahmed M. Serum and hair zinc in severely malnourished Bangladeshi children associated with or without acute lower respiratory infection. Indian J Pediatr 2009; 76:609-614.

10 Welsh DA, Mason CM. Host defense in respiratory infections. Med Clin North Am 2001; 85:1329-1347.
11 Srinivasan MG, Ndeezi G, Mboijana CK, Kiguli S, Bimenya GS, Nankabirwa $\mathrm{V}$, et al. Zinc adjunct therapy reduces case fatality in severe childhood pneumonia: a randomized double-blind placebocontrolled trial. BMC Med 2012; 10:14-24.

12 Basnet S, Mathisen M, Strand TA. Oral zinc and common childhood infections - an update. J Trace Elem Med Biol 2015; 31:163-166.

13 Shah GS, Dutta AK, Shah D, Mishra OP. Role of zinc in severe pneumonia: a randomized double bind placebo-controlled study. Ital J Pediatr 2012; 38:36-42.

14 Valentiner-Branth P, Shrestha PS, Chandyo RK, Maria M, Sudha B, Nita B, et al. A randomized controlled trial of the effect of zinc as adjuvant therapy in children 2-35 mo of age with severe or nonsevere pneumonia in Bhaktapur, Nepal. Am J Clin Nutr 2010; 91:1667-1674.

15 Jagnoor J, Suraweera W, Keay L, Ivers RQ, Thakur JS, Jha $P$. Unintentional injury mortality in India, 2005: nationally representative mortality survey of 1.1 million homes. BMC Public Health 2012; 12:487.

16 Chen $\mathrm{Y}$, Dales R, Lin M. The epidemiology of chronic rhinosinusitis in Canadians. Laryngoscope 2003; 113:1199-1205.

17 Prasad AS. Zinc deficiency: its characterization and treatment. Met lons Biol Syst 2004; 41:103-137.

18 Cvijanovich NZ, King JC, FloriHR, Gildengorin G, Wong HR. Zinchomeostasis in pediatric critical illness. Pediatr Crit Care Med 2009; 10:29-34.

19 Pediatric Society of New Zealand. Best practice evidence-based guideline: Wheeze and chest infection in infants under 1 year. Raumat Beach, Paraparaumu 5032: Paediatric Society of New Zealand 2005

20 Arıca S, Arıca V, Dag H, Kaya A, Hatipoglu S, Fenercioglu A, et al. Serum zinc levels in children of 0-24 months diagnosed with pneumonia admitted to our clinic. Int J Clin Exp Med 2011; 4:227-233.

21 Bhandari N, Bahl R, Taneja S, Strand T, Mølbak K, Ulvik RJ, et al. Effect of routine zinc supplementation on pneumonia in children aged 6 months to 3 years: a randomized controlled trial in an urban slum. BMJ 2002; 324:1358.

22 Rahim V, Mohammad V, Gholam-Hossian K, Mahmoud M. Effect of zinc supplementation in occurrence and duration of a common cold in schoolaged children during cold season: a double-blind placebo-controlled trial. Iran J Pediatric 2009; 19:376-380.

23 Prasad AS. Impact of the discovery of human zinc deficiency on health. $J$ Am Coll Nutr 2009; 28:257-265.

24 Christa FW, Robert EB. Zinc and the risk for infectious disease. Ann Rev Nutr 2004; 24:255-275.

25 Panneerselam R, Marimuthu B. Serum zinc level in children admitted with pneumonia at tertiary care children's hospital. Int J Sci Stud 2016; 4:283-285

26 Brooks WA, Yunus M, Santosham M, Wahed MA, Nahar K, Yeasmin S, et al. Zinc for severe pneumonia in very young children: a double-blind placebo-controlled trial. Lancet 2004; 36:1683-1688.

27 Mahalanabis D, Lahiri M, Paul D, Gupta S, Gupta A, Wahed MA, et al Randomized, double-blind, placebo-controlled clinical trial of the efficacy of treatment with zinc or vitamin A in infants and young children with a severe acute lower respiratory infection. Am J Clin Nutr 2004; 79:430-436.

28 Shakur MS, Malek MA, Bano N, Islam K. Zinc status well nourished Bangladeshi children suffering from an acute lower respiratory infection. Indian Pediatric 2004; 41:478-481.

29 Kumar PA, Kotlyarevska K, Dejkhmaron P, Reddy GR, Lu C, Bhojani MS, et al. Growth hormone (GH)-dependent expression of a natural antisense transcrip induces zinc finger E-box- binding homeobox 2 (ZEB2) in the glomerular podocyte: a novel action of gh with implications for the pathogenesis of diabetic nephropathy. J Biol Chem 2010; 285:31148-31156.

30 Anuradha B, Christian LC, Gunavathi H, John H, Moses P, Raghupathy P, et al. Efficacy of zinc in the treatment of severe pneumonia in hospitalized children $<2$ y old. Am J Clin Nutr 2006; 83:1089-1096.

31 Rady HI, Rabie WA, Rasslan HA, El Ayadi AA. Blood zinc levels in children hospitalized with pneumonia: a cross-sectional study. Egypt $J$ Chest Dis Tuberc 2013; 62:697-700. 